\title{
Realising Good Governance Through Legal Principles in Oil Mining Management in Cepu Block in Bojonegoro
}

\author{
Irnawati \\ Faculty of Law \\ Universitas Brawijaya \\ Malang, Indonesia \\ md.irnaa@gmail.com
}

\begin{abstract}
This paper is aimed to analyse the realisation of good governance through the legal principles concerning oil mining management in Cepu Block Bojonegoro. As the oil mining management in Cepu Block is prone to conflict in government either vertically or horizontally, this paper discusses how to realise good governance concerning oil mining management in Cepu Block bojonegoro? And how are just and social welfare-oriented legal principles reflected in the oil mining management in Cepu Block Bojonegoro? This research involves socio-legal research with a case study concerning oil mining management in Cepu Block. A picture regarding this issue can be obtained where the oil mining management in the area still brings injustice for people and it is prone to government conflict both vertically and horizontally. There should be three aspects (authority, procedure, and substance) required to set good go vernance and four basic legal principles to manage the oil mining fairly and transparently (the principle of monopoly by the state for the sake of social welfare, principle of effectiveness and efficiency, and principle of sustainability and transparency).
\end{abstract}

Keywords-governance, legal principles, oil mining management.

\section{INTRODUCTION}

Oil mining is often linked to exploitation and the absence of merit for the society. Distribution of territory for mining tends to trigger overlapping and conflict of interests over land use or areas and other issues where the necessity of the local community is mostly overlooked[1]. The rights of the communities like welfare can be fulfilled when the government has implemented principles that are relevant to Legislation. Article 33 of the 1945 Constitution of the Republic of Indonesia states (1) The economy shall be organized as a common endeavor based upon the principles of the family values, (2) Sectors of production which are important for the country and affect the life of the people shall be under the power of the State, (3) the land, the waters, and the natural resources within shall be under the power of the State and shall be used to the greatest benefit of the people.

Each area holds natural resource potential that varies. The potential could positively contribute to economic condition of an area[2], as what the oil mining in Cepu Block of Bojonegoro could give.
The effect caused by the existence of the oil mining is not only restricted to economic loss, but it also triggers alarming social chaos. For example, the conflict between the mining company and the local community escalates. Moreover, the agrarian pattern also experiences a change to mining community and last but not least, areas close to the mining site are polluted and damaged. Despite the measures taken to deal with the damage and pollution, they are not quite optimal and far from substantive justice[3].

The damage of sustainable development is the form of response towards the concept of conventional development that manages to increase economic values, although it fails in environmental and social as pects [4].

Mining resources management in Indonesia, such as gold mining in Timika managed by Freeport, Mobil Oil Loh Sumawe, and so forth, is expected to be able to bring societies to welfare and justice. However, injustice, poverty, and environmental damage are even close to the societies and this situation is seen controversial[5].

From poor quality of survival of societies and regional government, it is considered important that appropriate legal principle be implemented in oil mining management in Cepu Block Bojonegoro for the welfare of the societies.

Substantive justice will come to reality when sustainable development is based on the legal principle in the oil mining management in Cepu Bojonegoro.

This paper presents the following research problems: 1) how to establish a good governance for oil mining management in Cepu Block Bojonegoro? 2) How can the legal principle be reflected from oil mining management in Cepu Block Bojonegoro without overlooking the justice and welfare of the societies?

\section{RESEARCH METHODS}

This research employed qualitative method[6] with sociolegal research approach. The socio-legal study involves alternative approach that examines doctrinal studies towards the law. This approach is not only aimed to give attention to sociology or social science, but is also focused on law and legal studies [7]. The characteristics of socio-legal approach can be identified into two: 1) conducting textual study, in which legislation and policy can be critically analyzed and explained in terms of its meaning toward the legal subject, 
including the community living near Cepu Block; and 2) socio-legal study, which develops several new methods that are combination between legal method and social sciences (based on some clips of news from mass media and information related to oil mining management is sue in Cepu Block Bojonegoro). The result of the observation is then classified, interpreted and analyzed by using content analysis. The analysis result will find out a legal principle that can be used in oil mining management in Cepu Block Bojonegoro to realize good governance and welfare.

\section{RESULTS AND DISCUSSION}

Bojonegoro is a regency located in the western part, the south of East Java, directly bordered with Central Java. The Regency of Bojonegoro was once in the top one of the poorest area in East Java[8].

Bojonegoro succeeded to leave the status as the poorest region in 2013 due to oil and gas, and earlier in 2010 Tuban already started to mine gas and oil.

The discovery of oil in Cepu Block is really a priceless gift, as the natural resource reserves are running out in Indonesia. It is perceived by most that this gift is priceless values that can bring people to welfare.

Oil mining management in Cepu is prone to conflict in governments either vertically or horizontally. The central government should supress the management of oil mining in Cepu for the sake of social responsibility[9]. When the central government cannot bring welfare to its people living in regional areas, the regional government of an autonomous area should call for justice in terms of equal share from the central government.

\section{A. Realising Good Governance}

To realise good governance, the three following aspects, according to Philipus M. Hadjon, need to be set in terms of decision making for societies: 1) authority, meaning that the official concerned should act based on his/her authority and existing regulation; 2) procedure related to the relevance to the required procedure according to transparency principle in the government; and 3) substantive aspect, which involves inexistent decision object or error in re[10].

Realising good governance requires appropriate procedure of oil mining management, especially for oil mining in Cepu Bojonegoro in post-nationalisation, which is important to know[11].

Bureaucracy reformation policy addressed to regional or state development relies on bureaucracy reformation target in realising and establishing good governance. The target involves: 1) realising clean bureaucracy, 2) realising effective and efficient bureaucracy, 3) realising productive bureaucracy, 4) realising transparent bureaucracy, and 5) realising decentralised bureaucracy [12].

Realising good governance also required environmental management in Indonesia. Siti Sundari Rangkuti states that the substance of Law on environmental management should hold principles of environmental policy to be put into regulation that comprises the following legal norms: a) abatement at the source, b) the best available technology $(\mathrm{BAT})=$ the "alara principle" (as low as reasonably achievable), c) the polluter pays principle, d) Stand still principle, e) principle of Regional Differentiation, and e) shifting the burden of proof = "het beginsel van de omkering der bewijslast[13][14]".

\section{B. Fair Legal Principle in Oil Mining Management in Cepu Block Bojonegoro}

Mining is defined as a part of or a whole activity conducted for observation, management, and mineral or coal production, which involve general investigation, exploitation, feasibility study, construction, mining, management and purification, loading and sale, and postmining activities [15]

Mining work site (WKP) covers three regencies: Regency of Blora, Central Java, Regency of Bojonegoro East Java, and Regency of Tuban East Java. As referred to oil and gas distribution map, the Regency of Bojonegoro accounts for the biggest oil and gas natural resource $(65.34 \%)$, followed by the Regency of Blora $(34.66 \%)$, and the Regency of Tuban with no oil and gas resource (0\%)[16].

Mining site in Cepu Block in Bojonegoro also holds basic legal principle in the oil mining management that comes with justice. The intended legal principle is listed as follows:

1. The principle of controlling right by the state and for the welfare of societies.

Styiglits argues that the involvement of private sectors in oil and gas management merely brings the state to loss. For the involvement of the private and foreign sectors that has happened, renegotiation on the cooperative contract in gas and oil is required. Success can be seen in Latin America where contract is amended for better agreement for both parties through renegotiation[5].

Kurtubi shares the same opinion as Styiglits, where oil and gas management in Indonesia that involves foreign parties and contract of work as the model have caused loss for the state, like the mining issue in Freeport in Papua and Newmont in North Sulawesi. It is simply because the contract is the legacy from the Dutch colonialists, which gradually takes state's asset. With this principle, mining in Indonesia or in Cepu Block could give benefit to the societies.

\section{Principle of effectiveness and efficiency}

Cepu Block will produce 160 thousand barrels when managed maximally and according to regulation. Central and Regional Governments are expected to be able to accelerate oil production because of high world oil price and it will surely give huge impact to the societies of Indonesia.

Appropriate decision made by the government regarding the management of oil mining in Cepu should also receive supports from all parties. The government seems to be focused on optimal supervision of the management in Cepu instead of blaming parties over the late management in Cepu.

\section{Principle of sustainability}

The principle of sustainability is related to a new discovery of oil in areas other than Cepu. As referred to Sindo newspaper, oil companies will keep looking for new sites where oil could be mined. Therefore, youth 
generation involvement is required in term of their idea contribution to enhance the quality of human resource for independent oil management in Indonesia.

4. Principle of transparency

Operationally, Oil mining management in Cepu Block is delegated to Exxon Mobil Oil. The right of Exxon Mobil to manage the mining in Cepu has attracted speculations from several movements. Gerakan Rakyat Penyelamat Cepu Block (GRPBC) or Cepu Block Rescuing Movement is one of movements that consists of several national figures such as Amien Rais, Kwiek Kian Gie, and several members of Regional Representative Board of the Republic of Indonesia such as Laoda Ida and Marwan Batubara, members of the House of Representatives of the Republic of Indonesia such as Drajat Wibowo and Alvin Lie, and some other elements, in which there are 110 members in total[17].

GRPBC argues that Cepu must be managed by the state. Drajat Wibowo suggests that the state will gain Rp. 51 trillions annually when Cepu Block is managed by Pertamina. In contrast, the state will only receive Rp. 30 trillions per year when the right to manage is held by Exxon Mobil. Vanessa, a member of Revenue Watch or International non-govemment organisation has warned those involved in the management of Cepu Block to have transparent finance, and the management should be based on the principle of trans parency [5].

\section{CONCLUSION}

1. Establishing good governance in oil mining management in Cepu Block of Bojonegoro requires the following main strategies that consist of three regional government aspects such as authority, procedure, and substantive aspect in all respects.

2. Basic legal principle is reflected in oil mining management in Cepu Block of Bojonegoro according to Law Nu mber 4 of 2009 on Coal and Mineral Mining and according to 4 principles: the principle of right to control by the state for the social welfare, the principle of effectiveness and efficiency, the principle of sustainability, and the principle of transparency.

\section{RECOMMENDATION}

1. It is important for the central government to give attention to the welfare of societies to realise good and fair governance
2. It is important that regional government supervise and work with central government to bring welfare to the societies according to the preamble of the 1945 Constitution of the Republic of Indonesia.

\section{REFERENCES}

[1] Rudi M. Simamora, Hukum Minyak dan Gas Bumi. Jakarta: Djambatan, 2000.

[2] D. R. P. Purnamaningsih, "Pengaruh Kawasan Migas terhadap Pola dan Struktur Ruang Perkotaan Kecamatan Kapas Kabupaten Bojonegoro," J. Pembang. Wil. dan Kota, vol. 13, no. 1, 2017.

[3] F. B. Butar, "Penegakan Hukum Lingkungab di Bidang Pertambangan," Yuridika, vol. 25, no. 2,p. 153, 2017.

[4] I. J. Azis, Pembangunan Berkelanjutan: Peran dan Kontribusi Emil Salim. Jakarta: Kepustakaan Populer Gramedia, 2010.

[5] Subadi, "Reorientasi Prinsip-Prinsip Hukum dalam Pengelolaan Tambang Migas di Blok Cepu Kabupaen Bojonegoro," Sosial, vol. 12, no. 1, p. 77, 2011.

[6] Hamid Patilima, Metode Penelitian Kualitatif. Bandung: Alfabeta, 2007.

[7] Sulistyowati Irianto, Memperkenalkan Kajian Sosio Legal dan Implikasi Metodologisnya Kajian Sosio Legal. Bali: Pustaka Larasan, 2012

[8] "Bojonegoro Sudah Tidak masuk 10 Besar Kabupaten Termiskin," $2017 . \quad$ [Online]. Available: http://www.bojonegorokab.go.id/berita/baca/2497/BojonegoroSudah-Tidak-masuk-10-Besar-Kabupaten-Termiskin-.

[9] Fachmi Rochmaningrum, "Perkembangan Tambang Minyak Blok Cepu dan Pengaruhnya terhadap Sosial Ekonomi Masyarakat Desa Ledok Tahun 1960-2004," J. Indones. Hist., vol. 1, no. 2, p. 96, 2012.

[10] T. S. D. Philipus M. Hadjon, Argumentasi Hukum (Legal Argumentation/ Legal Reasoning) Langkah-langkah Legal Problem Solving dan Penyusunan Legal Opinion. Yogyakarta: Gadjah Mada University Press, 2011.

[11] Siti Nur Fatimah, "Nasioalisasi Tambang Minyak di Cepu dan Pengelolaanya Tahun 1950-1966," J. Indones. Hist., vol. 5, no. 1, p. $54,2010$.

[12] Idup Suhady, "Kepemerintahan yang Baik," in Modul Diklat Prajabatan Gol. I dan II, Lembaga Administrasi Negara Republik Indonesia, 2009, pp. 67-68.

[13] F. B. Butar, "Penegakan Hukum Lingkungan di Bidang Pertambangan," Yuridika, vol. 25, no. 2, p. 155, 2010.

[14] Siti Sundari, "Perangkat Hukum Lingkungan: Dari Ius Constitutum, Sekali Lagi, Ke Ius Constituendum," in Good Governance and Good Environmental Governance, 2008, p.5.

[15] Law Number 4 of 2009 on Mineral Mining and Coal. 2009.

[16] S. Titik Kurniawati, Wiwik Widayati, "Kesenjangan Fiskal Dana Bagi Hasil Minyak dan Gas Bumi atas Eksploitasi Blok Cepu," J. Ilmu Pemerintah., p. 6, 2013.

[17] N. . Mahmud, "Berharap Sejahtera dari Semburan Minyak,” 2014. [Online]. Available: http://www.ireyogya.org/461/. 